\title{
Groundwater Aquifer Vulnerability Assessment using a Dar-Zarrouk Parameter in a Proposed Aboru Residential Estate, Lagos State, Nigeria
}

\author{
AYUK, MA \\ Department of Applied Geophysics, Federal University of Technology, Akure, Nigeria. \\ *Email:ayukmike2003@yahoo.com;Tel.:+2348035223352
}

\begin{abstract}
The need to build an automobile mechanic settlement, abattoir and a proposed meat processing factory at Aboru residential estate necessitated a geophysical assessment (using a Dar-Zarrouk parameter - longitudinal unit conductance, S) of the vulnerability of the subsurface aquifers in the study area against the expected long-term anthropogenic impacts of these facilities on the groundwater system. Thirteen (13) Vertical Electrical Sounding (VES) points and four (4) Dipole-Dipole resistivity profile lines were occupied on four traverse lines across the study area. Isoresistivity and Isopach maps were generated and Total Longitudinal Unit Conductance, $\mathrm{S}$ of the earth materials overlying the aquifer was computed and the aquifer protective capacity (APC) map was generated. The VES delineated four (4) geo-electric layers namely; topsoil, pebbly/lateritic sand, clay/clayey/silty sand and sandstone. The depth to the sandstone aquifer ranges from $30.6-39.4 \mathrm{~m}$ with resistivity values ranging from $851-1437 \Omega \mathrm{m}$. The iso-resistivity and isopach maps reveal that the near surface lateritic materials with resistivity values ranging from $350-1150 \Omega \mathrm{m}$ and thicknesses ranging from $2-29 \mathrm{~m}$ are pervious. The Total Longitudinal Unit Conductance, $\mathrm{S}$ varies from 0.0164 - 0.1168 mhos indicating a poor to weak protective capacity rating across the study area and the APC map reveals that the north-eastern and western parts of the study area show areas with weak protective capacity ratings while other areas are characterized by poor protective capacity rating. As such, the establishment of the proposed service facilities in the study area is strongly discouraged as the nature of their operations has a high potential to contaminate and eventually pollute the sub-surface aquifers on the long-run. If however the inevitability of their establishment cannot be set-aside, then secondary measures must be taken to forestall a direct impact of their operations on the subsurface.
\end{abstract}

\section{DOI: $\underline{\text { https://dx.doi.org/10.4314/jasem.v23i12.2 }}$}

Copyright: Copyright (C) 2019 Ayuk. This is an open access article distributed under the Creative Commons Attribution License (CCL), which permits unrestricted use, distribution, and reproduction in any medium, provided the original work is properly cited.

Dates: Received: 04 October 2019; Revised: 11 November 2019; 23 November 2019

Keywords: Aquifer, Dar-Zarrouk, Vulnerability, Longitudinal Unit Conductance

The geoelectrical resistivity method has been successfully employed in the delineation of subsurface geological sequence, geological structures/features of interest, aquifer units, types and depth extent in almost all geological terrains (Oladapo et al. 2004; Ako et al. 2005; Lashkaripour et al., 2005; Hassanein et al. 2007). This is because of the significant resistivity contrasts that exist between different earth materials (Olorunfemi and Fasuyi 1993). The resistivity method can therefore map interface along which a resistivity contrast exists. This interface may or may not coincide with geological boundary (Telford et al. 1990). In addition, vertical electrical sounding (VES) has been widely used to evaluate groundwater potentials and area of high groundwater yield (Ako and Osondu 1986; Abdulaziz 2005; Abiola et al. 2009). Geoelectrical methods are also used extensively in groundwater mapping for investigation of the vulnerability of shallow aquifers (Abiola et al. 2009). The vulnerability of aquifers is largely dependent on the presence or absence of protective impermeable layer, usually clay. The earth medium acts as a natural filter to percolating fluid; its ability to retard and filter percolating fluid is a measure of its protective capacity
(Olorunfemi et al,. 1998). Studies such as Sørensen et al. (2005) have shown that geoelectrical method is an invaluable tool in mapping aquifer vulnerability because of its capability to distinguish low- and highresistive formations. The concept of groundwater vulnerability is based on the assumption that the physical environment may provide some degree of protection to groundwater against natural impacts, especially with regard to contaminants entering the subsurface zone. Consequently, some land areas are more vulnerable to groundwater contamination than others. Henriet (1976) showed that the combination of layer resistivity and thickness in the Dar Zarrouk parameters $\mathrm{S}$ (longitudinal conductance) and $\mathrm{T}$ (transverse resistance) may be of direct use in aquifer protection studies and for the evaluation of hydrologic properties of aquifer. The protective capacity is considered to be proportional to the longitudinal unit conductance in mhos (Olorunfemi et al., 1998; Oladapo et al., 2004; Ayolabi, 2005 and Atakpo and Ayolabi, 2009).

Aboru mini-estate is a large densely populated residential area of Lagos whose sources of water are

*Email: ayukmike2003@yahoo.com; Tel.: +2348035223352 
three industrial groundwater boreholes that tap the groundwater from a deep seated sandstone/sand aquifer at three strategic locations in the estate. Automobile mechanic settlement, abattoir and meat processing factory have been proposed to be established in the estate due to urbanization and selfsustainability of the area. The operations of these service facilities have high potential to contaminate and pollute the sub-surface aquifers in the study area on the long-run due to the possibility of indiscriminate dumping of waste on the ground surface from these facilities. This therefore has necessitated the aquifer vulnerability study in the study area. In this study therefore, 2D dipole-dipole and 1D vertical electrical sounding (VES) geophysical techniques were applied to determine the first order geoelectric parameters (resistivity $\rho$ and thickness $h$ ) to delineate the depth to aquifer and its lateral extent and a second order geoelectric parameter (longitudinal unit conductance) to determine the aquifer protective capacity.

\section{MATERIALS AND METHODS}

Study area: Geologically, Lagos state falls within Eastern Dahomey Basin. The stratigraphy of Cretaceous to Tertiary sedimentary sequence of the Eastern Dahomey Basin is divided into: Abeokuta Group, Imo Group, Ilaro Formation, Benin Formation, Coastal plain sands and recent alluvium (Omatsola and Adegoke, 1981). The study area is underlain by the Coastal Plain Sands of Lagos (Fig. 1). Aboru (Fig. 2) is located in Iyana-Ipaja area of Lagos, southwestern Nigeria. It lies between Northing $732983 \mathrm{mN}$ and $733097 \mathrm{mN}$ and Easting $530651 \mathrm{mE}$ and $530771 \mathrm{mE}$ (Fig. 2). The two prevailing climatic seasons are the dry (November to March) and wet (April to October) seasons and it is found in the rain forest environment with mean annual rainfall ranging between $1500 \mathrm{~mm}$ and $2500 \mathrm{~mm}$ (Balogun, 2000).

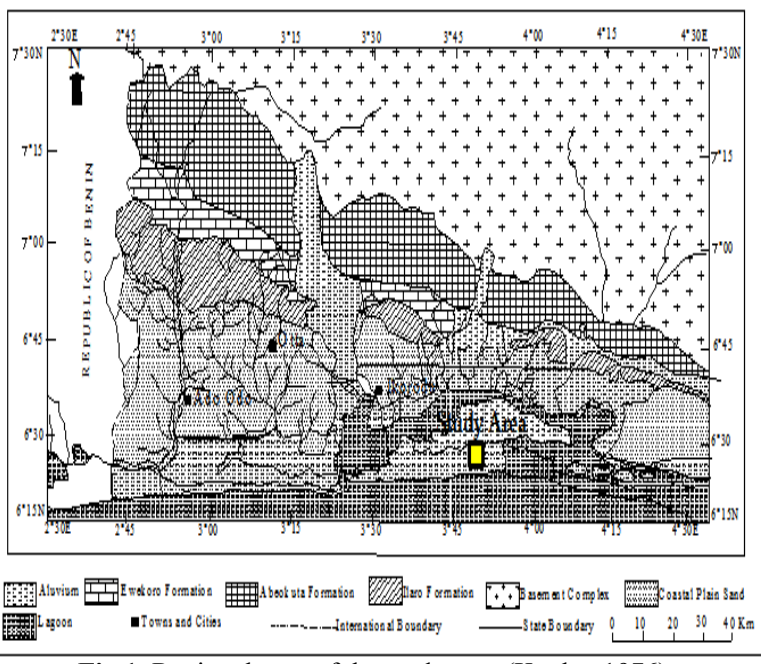

Fig 1: Regional map of the study area (Kogbe, 1976)

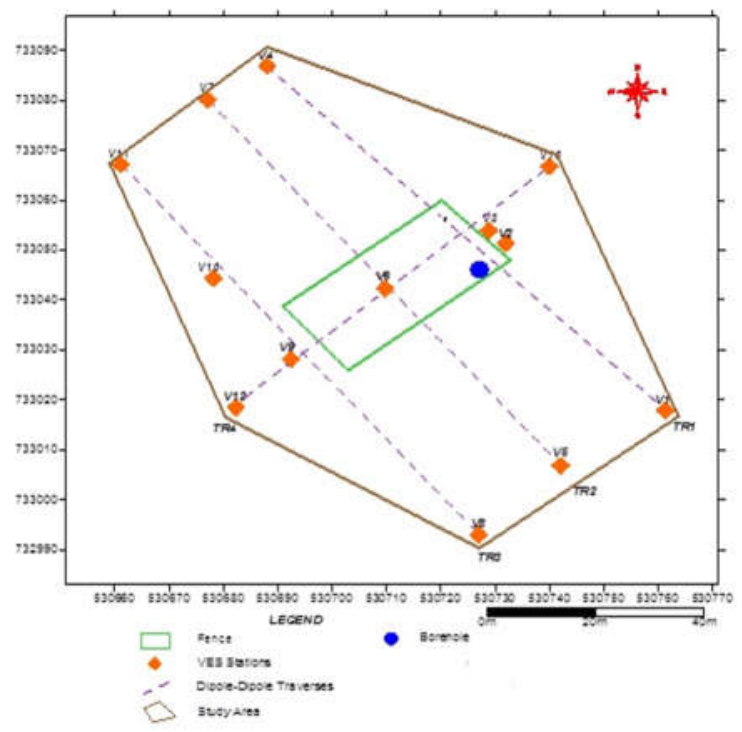

Fig 2: Base map of the study area

Data Acquisition: Geophysical Investigation: 2D dipole-dipole electrical resistivity measurements were taken along four (4) traverses using the R-50 Soil Test Resistivity Meter. Traverses 1-3 run in SE-NW direction while traverse 4 runs in approximately SWNE direction (Fig. 2). Electrode separation of $5 \mathrm{~m}$ and inter-dipole expansion factor (n) was varied from 1-5 along the four traverses. Traverse 1-3 each have a total surface length of $100 \mathrm{~m}$ while traverse 4 has a total surface length of $80 \mathrm{~m}$. Following the 2D dipoledipole measurement, a total of thirteen (13) VES data were acquired within the study area using the Schlumberger Array type. Four VES points (V1 to V4) were on TR1, three VES points (V5 to V7) on TR2, four VES points (V8 to V11) on TR3 and two VES points (V12 to V13) on TR4 as shown in figure 2. The highest half-current electrode spread length $(\mathrm{AB} / 2)$ is $65 \mathrm{~m}$.

Data Processing: Geophysical Investigation: The 2D Dipole-Dipole data sets were processed for inversion with DiproWin Software to generate the pseudo sections and calculate the true resistivity distribution within the area. Anomalous resistivity points were identified across the sections and these were later occupied with the VES. The VES sounding curves so generated were processed with partial curve matching to quantitatively generate the first order geoelectric parameters. These were used as input parameters for inversion using WINRESIST iteration software. Spatial correlations of the resistivity, thickness and depth were used to generate the geoelectric sections along the traverses.

Dar-Zarrouk Parameters: Dar-Zarrouk (D-Z) parameters were defined by Maillet (1947). $T$ is the 
resistance normal to the face and $\mathrm{S}$ is the conductance parallel to the face for a unit cross section area, which plays an important role in resistivity soundings. D-Z parameters are sufficient for computing the distribution of surface potential and hence an electrical resistivity graph (Henriet 1976).

Suppose that a section consists of $\mathrm{N}$ fine layers with thickness $h_{1}, h_{2}, \ldots \ldots . ., h_{n}$ and resistivity $\rho_{l}, \rho_{2}$, $\rho_{3}, \ldots \ldots \ldots, \rho_{n}$ for a block of unit square area and thickness $H=\sum_{i=1}^{N} h_{i}$

These values of $\mathrm{S}$ and $\mathrm{T}$ are set equal to those for an anisotropic block with unit square area. So that: Longitudinal Unit Conductance S,

$$
S=\frac{h_{1}}{\rho_{1}}+\frac{h_{2}}{\rho_{2}}+\frac{h_{3}}{\rho_{3}}+\cdots \ldots \ldots+\frac{h_{n}}{\rho_{n}}=\sum_{i=1}^{N} \frac{h_{i}}{\rho_{i}} \ldots 1
$$

Transverse Unit Resistance T,

$$
\begin{gathered}
T=\rho_{1} h_{1}+\rho_{2} h_{2}+\rho_{3} h_{3}+\cdots \ldots \ldots+\rho_{n} h_{n}= \\
\sum_{i=1}^{N} \rho_{i} h_{1} \ldots 2
\end{gathered}
$$

Longitudinal Resistivity $\mathrm{R}_{\mathrm{S}}$,

$$
R_{s}=\frac{H}{S}
$$

Transverse Resistivity, $\mathrm{R}_{\mathrm{T}}$

$$
R_{T}=\frac{T}{H}
$$

In this study however, only the Longitudinal Unit Conductance $\mathrm{S}$ in mhos (Equation 2) was considered as it is found to be proportional to the protective capacity of the overburden (Olorunfemi et al., 1998; Oladapo et al., 2004. Ayolabi, 2005 and Atakpo and Ayolabi, 2009).

\section{RESULTS AND DISCUSSION}

Geophysical Investigation: 2D Resistivity Imaging: Figs. 3-6 present the 2D resistivity structure for traverse $1-4$. Traverse 1-3 are oriented in the SE-NW direction (Figs. 3-5). Traverse 4 is oriented in SW-NE direction (Fig. 6). In SE-NW direction (Figs. 3-5), lateral distance of $90 \mathrm{~m}$ was covered and a depth of 15 $\mathrm{m}$ was imaged. Resistivity varies from 70 to $1047 \Omega \mathrm{m}$ across traverses $1-3$ in this orientation. Resistivity distribution across this direction reveals two distinct resistivity structures indicating clayey/clayey sand/sandy topsoil (with an indication of being lateritic on traverse 2) and lateritic sand (which is likely to be pebbly in nature). Topsoil resistivity and thickness range from $70-825 \Omega \mathrm{m}$ and $2-3 \mathrm{~m}$ respectively. The resistivity and thickness of the lateritic sand range from 477 (in traverse 2) - $1047 \Omega \mathrm{m}$ (in traverse 1) and $12-13 \mathrm{~m}$.

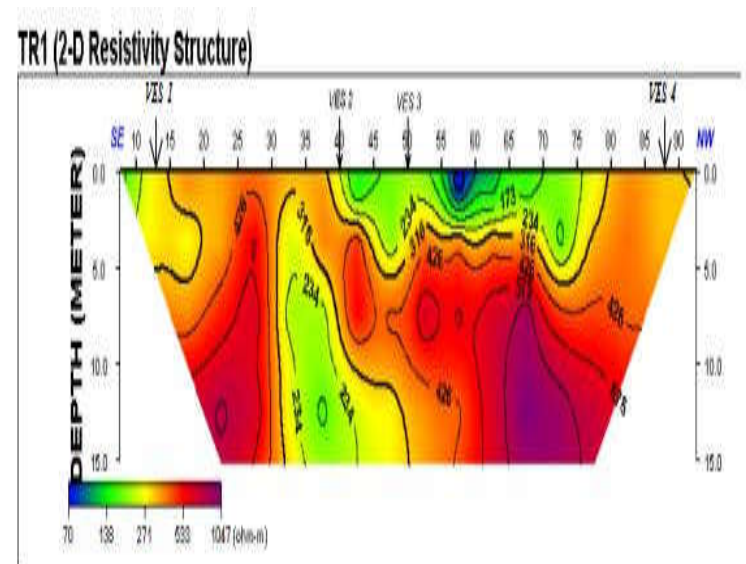

Fig 3: 2-D resistivity structure along traverse 1 in SE-NW direction

Across these traverses $1-3$, resistivity signatures are fairly similar and subsurface parameters are fairly uniform because the traverses orient in the same direction i.e SE-NW (Fig. 2). Across these traverses (1-3) in this direction and at $15 \mathrm{~m}$ depth, there seems to be no resistivity structure that could be of good hydrogeological significance for groundwater exploitation.

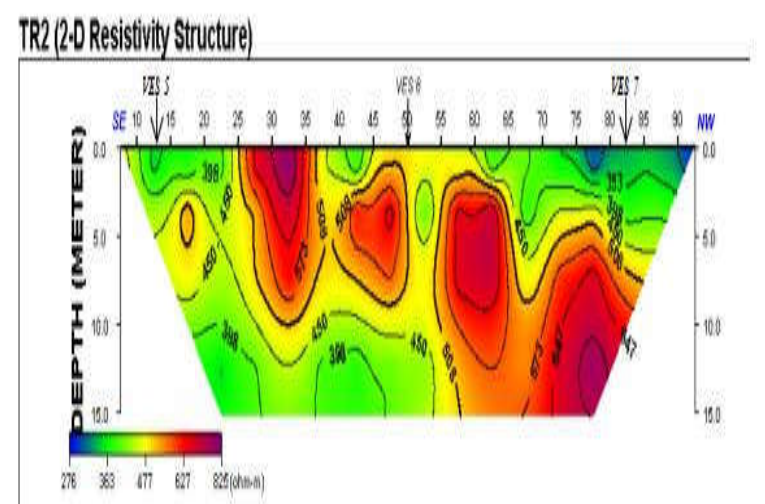

Fig 4: 2-D resistivity structure along traverse 2 in SE-NW direction

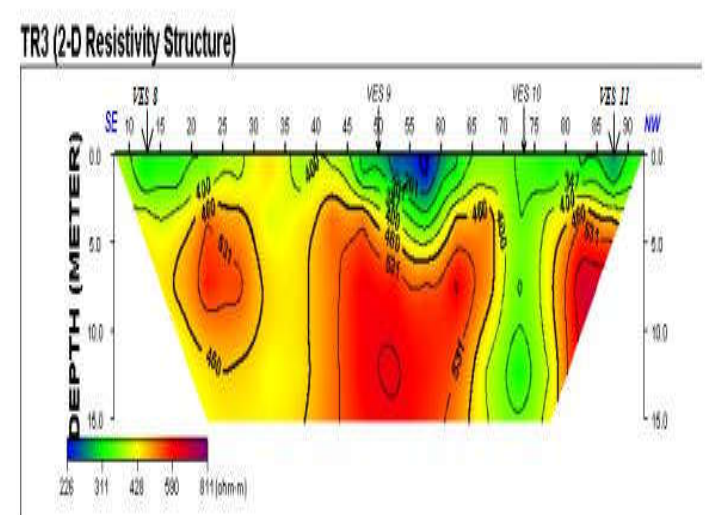

Fig 5: 2-D resistivity structure along traverse 3 in SE-NW direction 


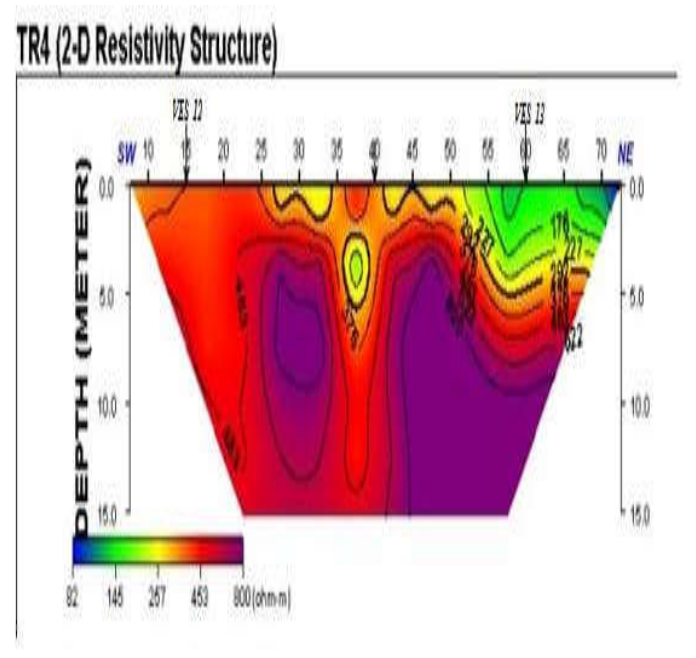

Fig 6: 2-D resistivity structure along traverse 4 in SW-NE direction

In SW-NE direction is traverse 4 (Figs. 2 and 6). Lateral distance of $70 \mathrm{~m}$ was covered and depth of 15 $\mathrm{m}$ was imaged (Fig. 6). The resistivity distribution along this traverse shows three distinct resistivity structures indicating the topsoil, clayey sand and lateritic sand. The topsoil, which is sandy in nature (with resistivity ranging from $227-483 \Omega \mathrm{m}$ ) is fairly continuous across the traverse up to $50 \mathrm{~m}$ lateral distance (Fig. 6). Beyond here, the topsoil is clayey sand with resistivity ranging from $145-176 \Omega \mathrm{m}$. The thickness of the topsoil ranges from $2-5 \mathrm{~m}$. The topsoil is underlain by a lateritic sand layer with resistivity and thickness ranging from $622-800 \Omega \mathrm{m}$ and $5-10 \mathrm{~m}$. The lateritic sand is not fairly continuous in the subsurface based on the resistivity distribution (Fig. 6). At the maximum depth of $15 \mathrm{~m}$ imaged, there is no indication of an aquifer.

$1 D$ Vertical Electrical Sounding (VES): The field curves obtained within the study area are the AK, KH, $\mathrm{KQ}, \mathrm{AKH}, \mathrm{KHK}$ and KHKH types with the AK-type being dominant. The AK curve type accounted for about $61.5 \%$ while the remaining curve types each accounted for $7.7 \%$ of the total curve types within the study area. Frequency distribution of the curve types is presented in Fig. 7 and a typical curve type from each traverse is presented in Fig. 8. The summary of the VES results is presented in Table 1. From the VES curves, four (4) to six (6) layers were delineated indicating topsoil, lateritic sand, pebbly sand, silty/clayey sand and sandstone. VES 11 reveals six (6) layers, VES 3 and 11 reveal five (5) layers while other VES curves reveal 4 layers. On traverse 1 (Fig. 9) are VES 1-4. Four (4) to five (5) layers are delineated along this traverse with four (4) layers in VES 1, 2 and 4 and five (5) layers in VES 3.

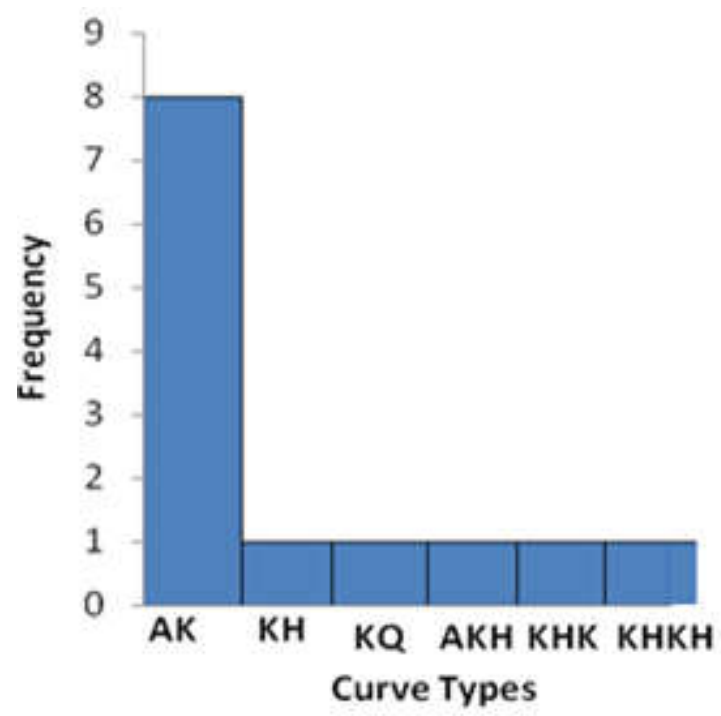

Fig. 7: Histogram of the curve types obtained in the study area

The topsoil, whose resistivity and thickness range from $25-135 \Omega \mathrm{m}$ and $0.7-1.1 \mathrm{~m}$ is underlain by pebbly sand in VES 1, 3 and 4 and by lateritic sand in VES 2 (Fig. 9). The resistivity and thickness of the pebbly sand range from $284-346 \Omega \mathrm{m}$ and $0.9-6.6$ $\mathrm{m}$ in VES 1, 3 and 4 while in VES 2, the resistivity and thickness of the lateritic sand are $2526 \Omega \mathrm{m}$ and $0.9 \mathrm{~m}$. The third layer in VES 1, 3 and 4 is the lateritic sand with resistivity and thickness ranging from $494-1172$ $\Omega \mathrm{m}$ and 3.9 - $23.4 \mathrm{~m}$ while in VES 2, the third layer is the pebbly sand with resistivity and thickness of 498 $\Omega \mathrm{m}$ and 2.4. Layer four along this traverse is silty sand across VES 1, 2 and 3. At VES 4, the fourth layer is clayey sand. The resistivity of the silty sand varies from $173-298 \Omega \mathrm{m}$ and its thickness is $28.2 \mathrm{~m}$ in VES 3 only. The resistivity of the clayey sand is $100 \Omega \mathrm{m}$. The thickness could not be determined because the current terminated at this zone. VES 3 is underlain by a fifth layer (Fig. 6) of sandstone with resistivity of $858 \Omega \mathrm{m}$, whose thickness could not be determined because the current terminated at this zone and the sandstone is suspected to be an aquifer of good hydrogeological significance. On traverse 2 (Fig. 10) are VES 5-7. Four (4) layers are delineated along this traverse. The topsoil, with resistivity and thickness ranging from $131-242 \Omega \mathrm{m}$ and $0.8-1.8 \mathrm{~m}$ is underlain by lateritic sand in VES 5 and 6 with resistivity and thickness varying from $601-966 \Omega \mathrm{m}$ and $0.6-1.5 \mathrm{~m}$ while in VES 7, the topsoil is underlain by pebbly sand with resistivity $285 \Omega \mathrm{m}$ and thickness $5 \mathrm{~m}$ respectively. The third layer on this traverse is silty sand, pebbly sand and lateritic sand on VES 5, 6 and 7 with corresponding resistivity $374 \Omega \mathrm{m} \&$ thickness $27.4 \mathrm{~m}, 573 \Omega \mathrm{m} \& 12.2 \mathrm{~m}$ and $639 \Omega \mathrm{m}$ and $13.3 \mathrm{~m}$ respectively. 


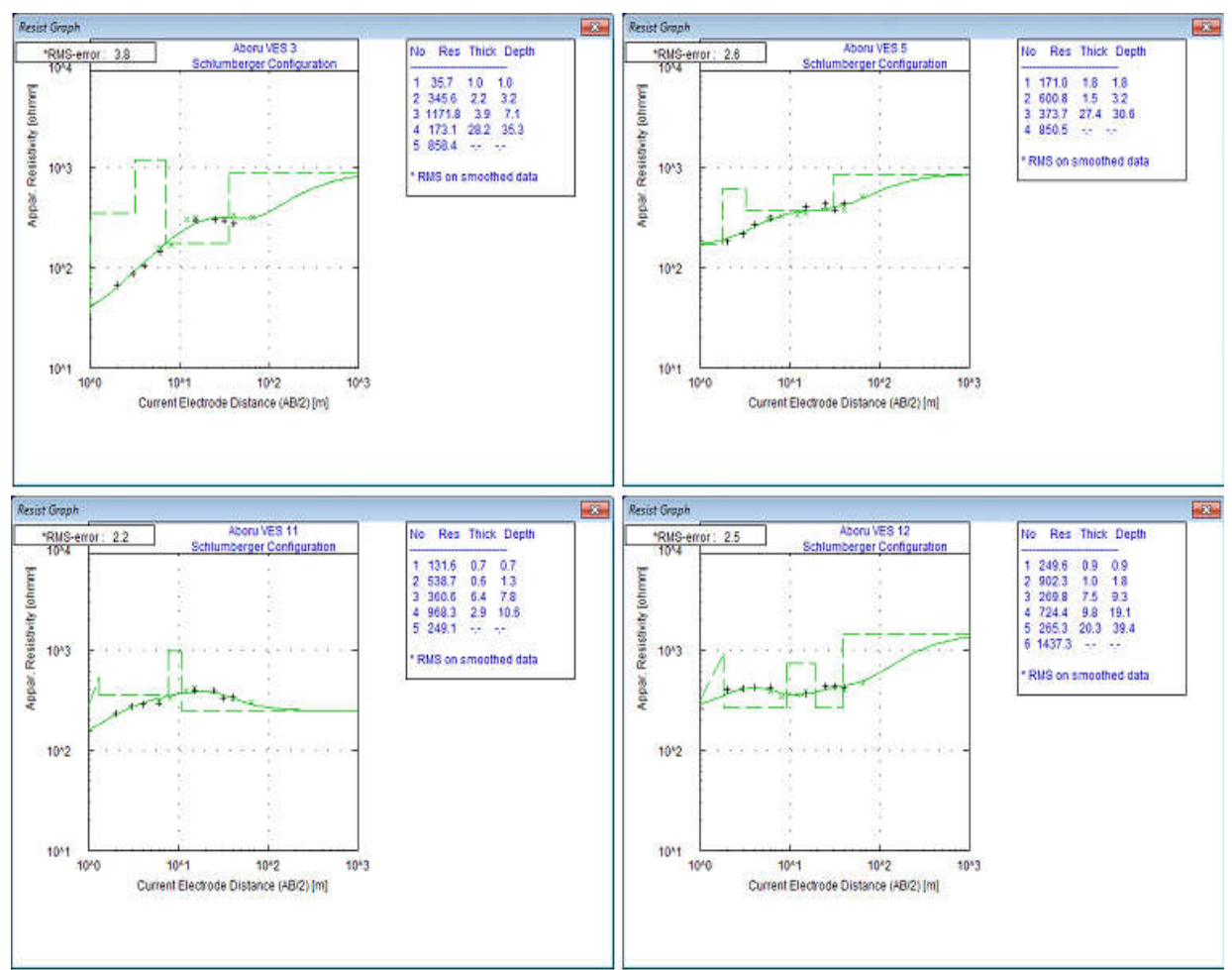

Fig. 8: Typical VES curve-type from each traverse 1-4

The third layer is underlain by sandstone in VES 5 and in VES 6 and 7; it is underlain by silty sand (Fig. 10). The resistivity of the sandstone is $851 \Omega \mathrm{m}$ while the resistivity of the silty sand varies from $264-372 \Omega \mathrm{m}$ in VES 6 and 7. Their thicknesses could not be determined because the current terminated at that depth. The sandstone at VES 5 is an aquifer. On traverse 3 (Fig. 11) are VES 8, 9, 10 and 11. Four (4) layers are delineated on this traverse.

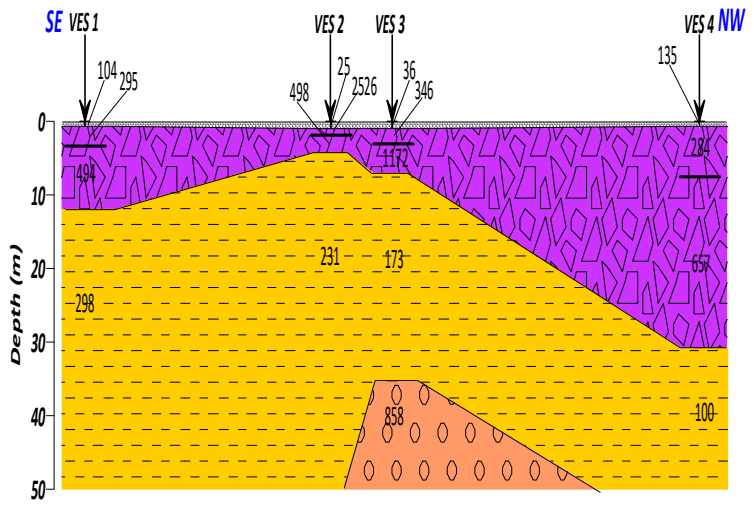

LEGEND

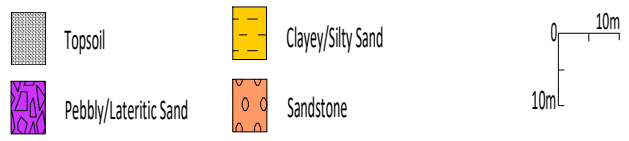

Fig. 9: Geoelectric section along traverse 1

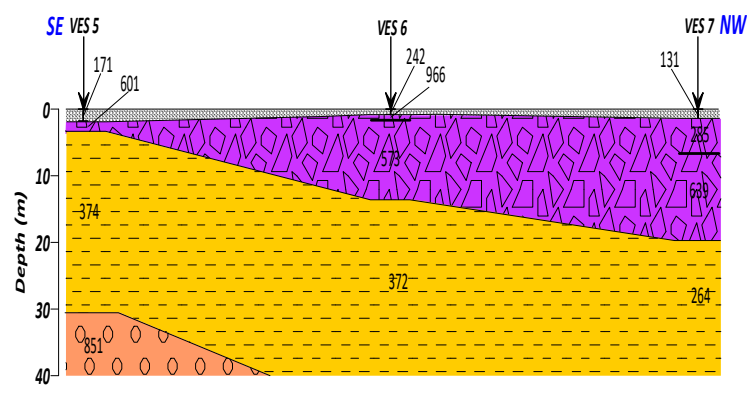

LEGEND

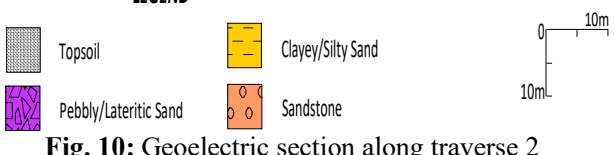

The topsoil, with resistivity and thickness ranging from $132-297 \Omega \mathrm{m}$ and $0.7-1.7 \mathrm{~m}$ is underlain by pebbly sand in VES 8 and 9 with resistivity and thickness varying from $314-569 \Omega \mathrm{m}$ and $4.6-5.0 \mathrm{~m}$ while in VES 10 and 11, the topsoil is underlain by lateritic sand with resistivity and thickness varying from $539-610 \Omega \mathrm{m}$ and $0.6-1.7 \mathrm{~m}$ respectively. The third layer on this traverse is lateritic sand, on VES 8 and 9 with corresponding resistivity and thickness varying from $638-1185 \Omega \mathrm{m}$ and $16.6-22.2 \mathrm{~m}$, while in VES 10 and 11 the third layer is silty sand and pebbly sand with resistivity and thickness of $391 \Omega \mathrm{m}$ and $38.9 \mathrm{~m}$ for the silty sand and $361 \Omega \mathrm{m}$ and $6.4 \mathrm{~m}$ for the pebbly sand respectively. 
Table 1: Summary of the VES Interpretation Results

\begin{tabular}{|c|c|c|c|c|c|c|c|}
\hline $\begin{array}{l}\text { VES } \\
\text { No. }\end{array}$ & $\begin{array}{l}\text { Curve } \\
\text { Type }\end{array}$ & $\begin{array}{l}\text { No. of } \\
\text { Layers }\end{array}$ & $\begin{array}{l}\text { Resistivity } \\
\text { Value ( } \mathbf{\Omega m})\end{array}$ & $\begin{array}{l}\text { Thickness } \\
\text { (m) }\end{array}$ & $\begin{array}{l}\text { Depth } \\
\text { (m) }\end{array}$ & $\begin{array}{l}\text { Inferred } \\
\text { Lithology }\end{array}$ & $\begin{array}{l}\text { Hydrogeological } \\
\text { Significance }\end{array}$ \\
\hline \multirow[t]{4}{*}{1} & $\mathrm{AK}$ & 1 & 104 & 0.8 & 0.8 & Topsoil & \\
\hline & & 2 & 295 & 2.7 & 3.5 & Pebbly Sand & \\
\hline & & 3 & 494 & 8.5 & 12.0 & Lateritic Sand & \\
\hline & & 4 & 298 & - & - & Silty Sand & \\
\hline \multirow[t]{4}{*}{2} & $\mathrm{AK}$ & 1 & 25 & 1.1 & 1.1 & Topsoil & \\
\hline & & 2 & 2526 & 0.9 & 1.9 & Lateritic Sand & \\
\hline & & 3 & 498 & 2.4 & 4.3 & Pebbly Sand & \\
\hline & & 4 & 231 & - & - & Silty Sand & \\
\hline \multirow[t]{5}{*}{3} & $\mathrm{AKH}$ & 1 & 36 & 1.0 & 1.0 & Topsoil & \\
\hline & & 2 & 346 & 2.2 & 3.2 & Pebbly Sand & \\
\hline & & 3 & 1172 & 3.9 & 7.1 & Lateritic Sand & \\
\hline & & 4 & 173 & 28.2 & 35.3 & Silty Sand & \\
\hline & & 5 & 858 & - & - & Sandstone & Aquifer \\
\hline \multirow[t]{4}{*}{4} & $\mathrm{AK}$ & 1 & 135 & 0.7 & 0.7 & Topsoil & \\
\hline & & 2 & 284 & 6.6 & 7.4 & Pebbly Sand & \\
\hline & & 3 & 657 & 23.4 & 30.8 & Lateritic Sand & \\
\hline & & 4 & 100 & - & - & Clayey Sand & \\
\hline \multirow[t]{4}{*}{5} & $\mathrm{KH}$ & 1 & 171 & 1.8 & 1.8 & Topsoil & \\
\hline & & 2 & 601 & 1.5 & 3.2 & Lateritic Sand & \\
\hline & & 3 & 374 & 27.4 & 30.6 & Silty Sand & \\
\hline & & 4 & 851 & - & - & Sandstone & Aquifer \\
\hline \multirow[t]{4}{*}{6} & $\mathrm{AK}$ & 1 & 242 & 0.8 & 0.8 & Topsoil & \\
\hline & & 2 & 966 & 0.6 & 1.4 & Lateritic Sand & \\
\hline & & 3 & 573 & 12.2 & 13.6 & Pebbly Sand & \\
\hline & & 4 & 372 & - & - & Silty Sand & \\
\hline \multirow[t]{4}{*}{7} & AK & 1 & 131 & 1.5 & 1.5 & Topsoil & \\
\hline & & 2 & 285 & 5.0 & 6.5 & Pebbly Sand & \\
\hline & & 3 & 639 & 13.3 & 19.8 & Lateritic Sand & \\
\hline & & 4 & 264 & - & - & Silty Sand & \\
\hline \multirow[t]{4}{*}{8} & $\mathrm{AK}$ & 1 & 297 & 1.5 & 1.5 & Topsoil & \\
\hline & & 2 & 314 & 5.0 & 6.6 & Pebbly Sand & \\
\hline & & 3 & 1185 & 16.6 & 23.2 & Lateritic Sand & \\
\hline & & 4 & 64 & - & - & Clay & \\
\hline \multirow[t]{4}{*}{9} & $\mathrm{AK}$ & 1 & 140 & 1.0 & 1.0 & Topsoil & \\
\hline & & 2 & 569 & 4.6 & 5.6 & Pebbly Sand & \\
\hline & & 3 & 638 & 22.2 & 27.6 & Lateritic Sand & \\
\hline & & 4 & 136 & - & - & Clayey Sand & \\
\hline \multirow[t]{4}{*}{10} & KQ & 1 & 156 & 1.7 & 1.7 & Topsoil & \\
\hline & & 2 & 610 & 3.0 & 4.7 & Lateritic Sand & \\
\hline & & 3 & 391 & 38.9 & 43.6 & Silty Sand & \\
\hline & & 4 & 330 & - & - & Clayey Sand & \\
\hline \multirow[t]{5}{*}{11} & KHK & 1 & 132 & 0.7 & 0.7 & Topsoil & \\
\hline & & 2 & 539 & 0.6 & 1.3 & Lateritic Sand & \\
\hline & & 3 & 361 & 6.4 & 7.8 & Pebbly Sand & \\
\hline & & 4 & 968 & 2.9 & 10.6 & Lateritic Sand & \\
\hline & & 5 & 249 & - & - & Silty Sand & \\
\hline \multirow[t]{6}{*}{12} & KHKH & 1 & 250 & 0.9 & 0.9 & Topsoil & \\
\hline & & 2 & 902 & 1.0 & 1.8 & Lateritic Sand & \\
\hline & & 3 & 270 & 7.5 & 9.3 & Pebbly Sand & \\
\hline & & 4 & 724 & 9.8 & 19.1 & Lateritic San & \\
\hline & & 5 & 265 & 20.3 & 39.4 & Silty sand & \\
\hline & & 6 & 1437 & - & - & Sandstone & Aquifer \\
\hline \multirow[t]{4}{*}{13} & $\mathrm{AK}$ & 1 & 15 & 0.6 & 0.6 & Topsoil & \\
\hline & & 2 & 176 & 5.9 & 6.6 & Pebbly Sand & \\
\hline & & 3 & 393 & 17.0 & 23.6 & Lateritic Sand & \\
\hline & & 4 & 81 & - & - & Clayey Sand & \\
\hline
\end{tabular}

The fourth layer in VES 8 is clay with resistivity of 64 $\Omega \mathrm{m}$ and in VES 9 and 10, the fourth layer is the clayey sand with resistivity ranging from 136 to $330 \Omega \mathrm{m}$. The thickness of this fourth layer could not be determined at these three VES locations because the current terminated in this zone. At VES 11, the fourth layer is lateritic sand with resistivity and thickness of $968 \Omega \mathrm{m}$ and $2.9 \mathrm{~m}$. This layer is underlain by silty sand of resistivity $249 \Omega \mathrm{m}$. The thickness could not be determined because the probing current terminated at this zone. On this traverse, there is no indication of the presence of an aquifer in the subsurface within the depth of investigation. 


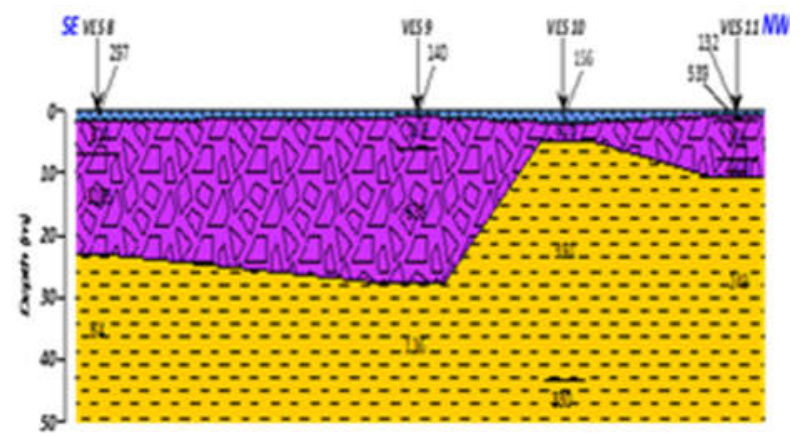

LEGEVO

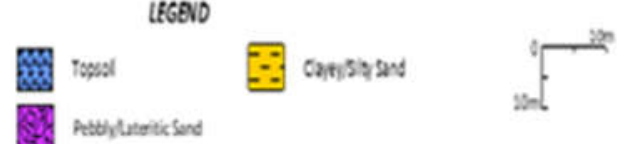

Fig. 11: Geoelectric section along traverse 3

On traverse 4 (Fig. 12) are VES 12 and 13. On this traverse are VES 9, 6 and 3 (Fig. 2) in a co-incidence due to traverse orientation (which has been discussed earlier and singly on their respective traverses). Four (4) and six (6) layers are delineated on VES 12 and 13 respectively. The topsoil, with resistivity and thickness ranging from $15-250 \Omega \mathrm{m}$ and $0.6-0.9 \mathrm{~m}$ is underlain by lateritic sand in VES 12 with resistivity and thickness $902 \Omega \mathrm{m}$ and $1.0 \mathrm{~m}$ while in VES 13, the topsoil is underlain by pebbly sand with resistivity and thickness of $176 \Omega \mathrm{m}$ and $5.9 \mathrm{~m}$ respectively. The third layer in VES 12 is pebbly sand with resistivity and thickness of $270 \Omega \mathrm{m}$ and $7.5 \mathrm{~m}$. In VES 13, the third layer is lateritic sand with $393 \Omega \mathrm{m}$ and $17 \mathrm{~m}$ resistivity and thickness values respectively.

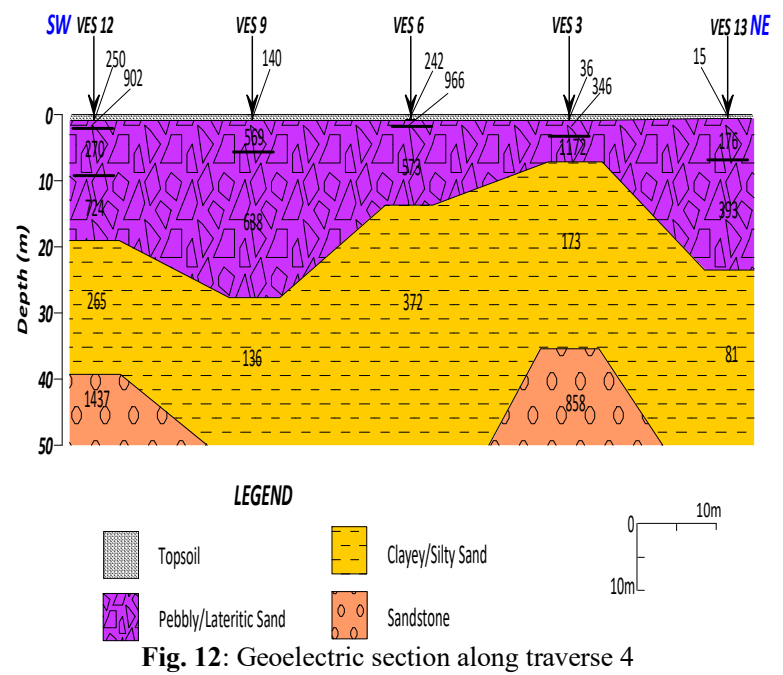

The fourth layer in VES 12 is lateritic sand with resistivity and thickness values of $724 \Omega \mathrm{m}$ and $9.8 \mathrm{~m}$ while the fourth layer in VES 13 is clayey sand with resistivity of $81 \Omega \mathrm{m}$. The thickness could not be determined because the current terminated at this point. The fifth layer in VES 12 is silty sand having resistivity and thickness values of $265 \Omega \mathrm{m}$ and $20.3 \mathrm{~m}$ respectively. The fifth layer is sandstone (Fig. 6d) with resistivity of $1437 \Omega \mathrm{m}$ but the thickness could not be determined because the probing current terminated at this point. The sandstone here is suspected to be of good hydrogeological significance. These results from the geoelectric sections correlate with the results from the 2D electrical resistivity sections (Fig. $3-6$ ). The 1D geoelectric investigation only images deeper depths than the 2D electrical resistivity investigation. There is a strong indication that the basal sandstone layer delineated by 1D geoelectric investigation at depth is the most suitable aquifer in the study area capable of supporting groundwater exploitation. The nature of the near-surface geologic materials overlying the aquifer is relatively porous and permeable thus offering little or no protection over the aquifer against contamination of any kind.

Iso-resistivity and Iso-pach Mapping of the Subsurface: Isoresistivity map of the subsurface layer (pebbly/lateritic sand) underlying the topsoil is presented in figure 13. The layer's average resistivity ranges from 350 to $1150 \Omega \mathrm{m}$. An almost uniform resistivity of $<750 \Omega \mathrm{m}$ is observed in the study area (Fig. 13). A closure of high resistivity ranging from $750-1500 \Omega \mathrm{m}$ is revealed in the south eastern part of the study area (Fig. 13) and this is typical of the highly resistive (but permeable) pebbly/lateritic sand delineated as the second layer in the geoelectric sections (Fig. 9-12) overlying the sandstone aquifer at depth. Isopach map of the second layer, which is the pebbly/lateritic sand, is presented in figure 14. The map shows a variation in the thickness of the pebbly/lateritic sand second layer within the study area. The thickness varies from 1 - $31 \mathrm{~m}$ (Fig. 14). In the NE-SW direction and slightly at the centre of the study area, the thickness varies from $13-31 \mathrm{~m}$. This result is indicated in the geoelectric section for traverse 4 (Fig. 12).

In NW - SE direction, the layer thickness varies from $1-11 \mathrm{~m}$ as also indicated in the geoelectric section for traverse 1-3 (Figs. 9 - 11). The relative thickness of the pebbly/lateritic sand; second layer in the study area does not give a protection to the underlying aquifer because of being a porous and permeable geologic material.

Evaluation of Aquifer Protective Capacity: Aquifer protective capacity (APC) is the ability of the overlying layers of rock (i.e the overburden) above the aquifer unit to impede, slow-down, filter and contain percolating ground surface contaminating fluids and run-offs. 


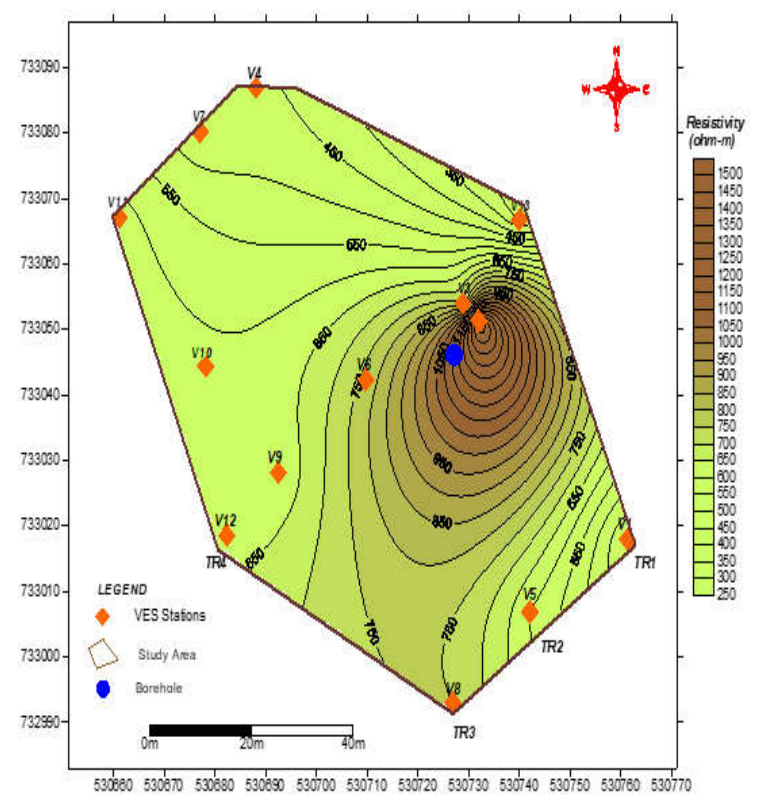

Fig. 13: Iso resistivity Map of the pebbly/lateritic sand

The second order geoelectric parameter - longitudinal conductance (which is a Dar Zarrouk parameter) was evaluated from the first order parameters (thickness and resistivity) of the geoelectric layers which were used in the classification of the APC of the area. Highly impervious materials such as clay and shale usually have high longitudinal conductance values (resulting from their low resistivity values) while pervious materials such as sand and gravels have low longitudinal conductance values (resulting from their high resistivity values). While high longitudinal conductance value corresponds to excellent and good APC, low longitudinal conductance values are associated with poor and weak APC (Tables 2 and 3).

Table 2: Longitudinal Conductance/Protective Capacity Rating (Henriet, 1976).

\begin{tabular}{lll}
\hline $\begin{array}{l}\text { Total Longitudinal Unit } \\
\text { Conductance (MHOS) }\end{array}$ & $\begin{array}{l}\text { Overburden } \\
\text { Capacity Classification }\end{array}$ \\
\hline$<0.10$ & Poor \\
$0.1-0.19$ & Weak & \\
$0.2-0.69$ & Moderate \\
$0.7-1.0$ & Good \\
\hline
\end{tabular}

Table 3: Modified Longitudinal Conductance/Protective Capacity

\begin{tabular}{ll}
\multicolumn{2}{c}{ Rating (Oladapo et al., 2004) } \\
\hline $\begin{array}{l}\text { Total Longitudinal } \\
\text { Unit Conductance } \\
\text { (MHOS) }\end{array}$ & $\begin{array}{l}\text { Soil Protective } \\
\text { Capacity } \\
\text { Classification }\end{array}$ \\
\hline$>10$ & Excellent \\
$5-10$ & Very Good \\
$0.7-4.9$ & Good \\
$0.2-0.69$ & Moderate \\
$0.1-0.19$ & Weak \\
$<0.1$ & Poor \\
\hline
\end{tabular}

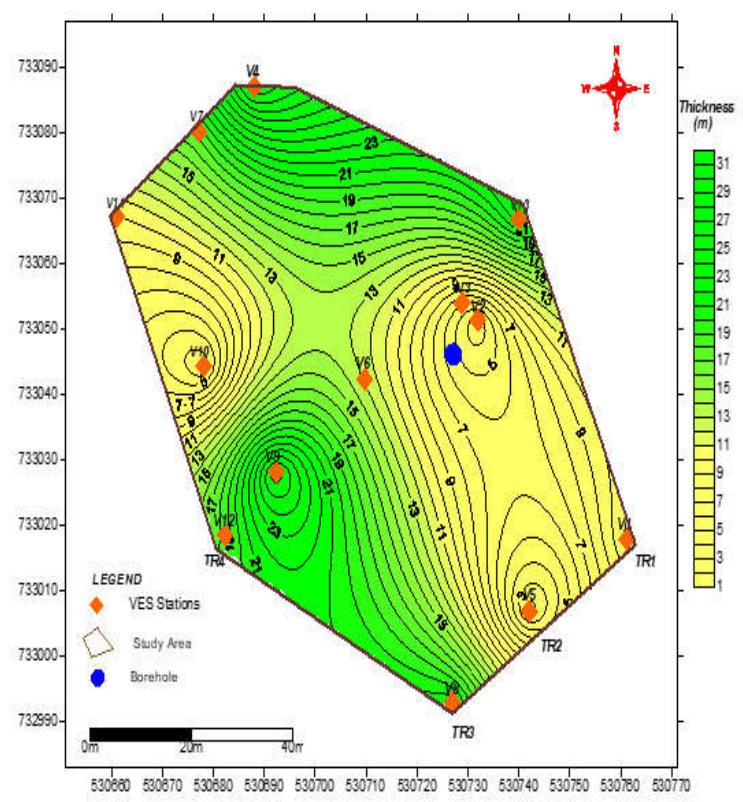

Fig. 14: Isopach Map of the pebbly/lateritic sand

Table 4 presents the summary of the computation of total longitudinal conductance $\mathrm{S}$ and overburden protective capacity rating at all the thirteen VES stations in the study area. From the analysis (Table 4), the value of the total longitudinal unit conductance varies from $0.0164-0.1168$ mhos in the study area and this signifies an overburden whose protective capacity is from poor to weak (Tables 2 and 3). This confirms the porous and permeable nature of the geologic materials (topsoil/pebbly sand/lateritic sand/clayey sand/silty sand) overlying the aquifer. Fig. 15 is the aquifer protective capacity map of the study area showing the spatial distribution of the longitudinal unit conductance across the study area. The north-eastern and western parts of the study area, accounting for $15 \%$ of the study area show areas with weak protective capacity ratings while other areas which represent $85 \%$ of the entire study area are characterized with poor protective capacity rating (Fig. 15). The weak and poor zones coincide with zones of shallow or thin overburden and relatively high electrical resistivity. These areas are vulnerable to easy and quick migration of near-surface/surface contamination sources. This result is in agreement with the interpreted or the inferred lithology across the study area for the overburden. From the interpreted geoelectric parameters, the inferred lithology for the layer directly overlying the aquifer is clayey sand/pebbly sand for the most parts of the study area. This lithologic unit is weak and porous in terms of its protective capacity and could offer little or no protection to the underlying aquifer as contaminating fluids can migrate relatively easy through this lithologic unit to pollute the aquifer. 
Table 4: Total Longitudinal Unit Conductance (S) and Overburden Protective Capacity Rating

\begin{tabular}{|c|c|c|c|c|c|c|c|c|c|c|c|}
\hline \multirow[b]{2}{*}{ VES } & \multicolumn{5}{|c|}{ Thickness of Layers (m) } & \multicolumn{4}{|c|}{ Resistivity of Layers $(\Omega \mathrm{m})$} & $\begin{array}{l}\text { Total Longitudinal } \\
\text { Unit Conductance, }\end{array}$ & \multirow{2}{*}{$\begin{array}{l}\text { Overburden } \\
\text { Protective Capacity } \\
\text { Rating (after Henxiet, } \\
\text { 1976; Oladapo et al, } \\
\text { 2004) }\end{array}$} \\
\hline & $h 1$ & $h 2$ & $h 3$ & $h 4$ & h5 & h6 61 & $\rho 2$ & $\rho 3$ & $\rho 4 \rho 5 \rho 6$ & $\mathrm{~S}=\sum_{t=1}^{n} \frac{h_{i}}{P_{l}}($ mhos $)$ & \\
\hline 1. & 0.8 & 2.7 & 8.5 & - & & 104 & 295 & 494 & - & 0.0341 & Poor \\
\hline 2. & 1.1 & 0.9 & 2.4 & - & & 25 & 2526 & 498 & - & 0.0492 & Poor \\
\hline 3. & 1.0 & 2.2 & 3.9 & 28.2 & - & 36.0 & 346 & 1172 & $174-$ & 0.0204 & Poor \\
\hline 4. & 0.7 & 6.6 & 23.4 & - & & 135 & 284 & 657 & - & 0.0640 & Poor \\
\hline 5. & 1.8 & 1.5 & 27.4 & - & & 171 & 601 & 374 & - & 0.0268 & Poor \\
\hline 6. & 0.8 & 0.6 & 12.2 & - & & 242 & 966 & 573 & - & 0.0252 & Poor \\
\hline 7. & 1.5 & 5.0 & 13.3 & - & & 131 & 285 & 639 & - & 0.0498 & Poor \\
\hline 8. & 1.5 & 5.0 & 16.6 & - & & 297 & 314 & 1185 & - & 0.0350 & Poor \\
\hline 9. & 1.0 & 4.6 & 22.2 & - & & 140 & 569 & 638 & - & 0.0500 & Poor \\
\hline 10. & 1.7 & 3.0 & 38.9 & - & & 156 & 610 & 391 & - & 0.1153 & Weak \\
\hline 11. & 0.7 & 0.6 & 6.4 & 2.9 & - & 132 & 539 & 361 & $96 \xi-$ & 0.0271 & Poor \\
\hline 12. & 0.9 & 1.0 & 7.5 & 9.8 & 20.3 & -250 & 902 & 270 & 724265 & 0.0164 & Poor \\
\hline 13. & 0.6 & 5.9 & 17.0 & - & & 15 & 176 & 393 & - & 0.1168 & Weak \\
\hline
\end{tabular}
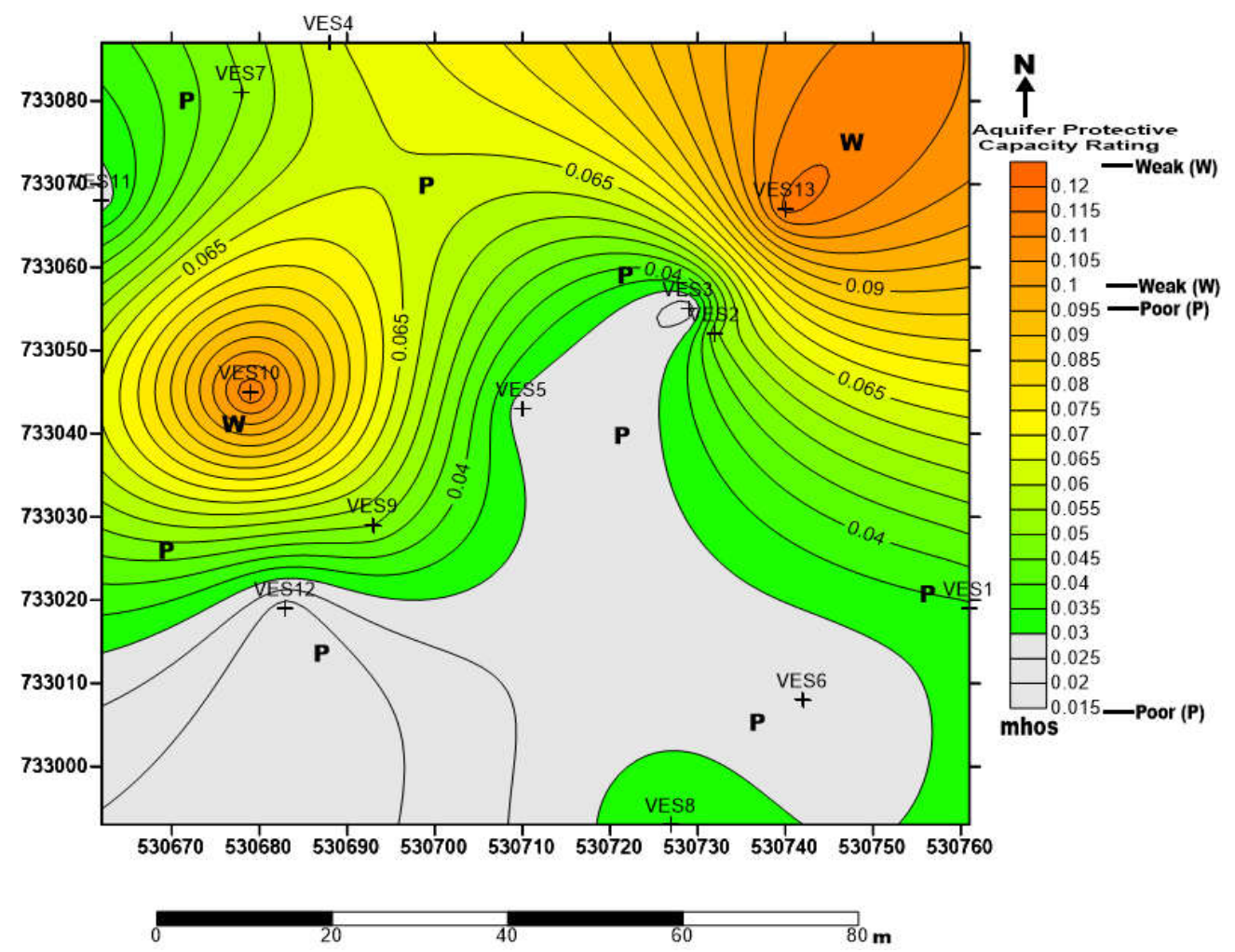

Fig. 15: Aquifer Protective Capacity Map of the Study Area

Conclusion: Due to expansion and self-sustainability, automobile mechanic settlement, abattoir and a meat processing factory have been proposed to be established at the Aboru Estate to serve as service facilities for the use of the increasing community. The operations of these service facilities such as the discharge of engine oil, blood and other fluids and solid materials are expected to impact the subsurface on the long-run with the high possibility of contamination and thereafter polluting the regional aquifer. As such, this necessitated a geophysical assessment (using Longitudinal Unit Conductance, S - a Dar-Zarrouk parameter) of the vulnerability of the subsurface aquifers in the study area against the expected long-term anthropogenic impacts of these facilities on the groundwater system. The aquifer protective capacity map reveals that the north-eastern and Western parts of the study area show areas with weak protective capacity ratings while other areas in study are characterized with poor protective capacity rating. This indicates that the aquifers are poorly protected and thus the earth materials overlying the aquifers have a poor protective capacity rating. The establishment of the proposed service facilities such as 
an automobile mechanic settlement, abattoir and a meat processing factory in the study area is strongly discouraged. The nature of the operations of these facilities has a high potential to contaminate and eventually pollute the sub-surface aquifers on the long-run. If however the inevitability of their establishment cannot be set-aside, secondary measures must be taken to forestall a direct impact of their operations on the subsurface.

Acknowledgement: The contributions of Mr. Akin-Ojo Tunji have been of immense help in improving the quality of this work.

\section{REFERENCES}

AKO, BD; AJAYI, TR; ARUBAYI, JB; ENU, EI (2005). The Groundwater and its Occurrence in the Coastal Plains Sands and Alluvial Deposits of Parts of Lagos State. Nigeria Water Res., 16: 717

AKO, BD; OSONDU, VC (1986) Electrical Resistivity of the Kerri-Kerri Formation, Darazo, Nigeria. J. Afri. Earth Sci. 5(5): 527-534

ABDULAZIZ, MA (2005). Resistivity Methods for Groundwater Exploration in the CretaceousTertiary Sedimentary Sequence, East of Jeddah, Saudi Arabia. J. Environ. Hydrology, 13(19): 111

ABIOLA, O; ENIKANSELU, PA; OLADAPO, MI (2009). Groundwater Potential and Aquifer Protective Capacity of Overburden Units in AdoEkiti, Southwestern Nigeria. Intl. J. of Physical Sci., 4(3): 120-132

ATAKPO, EA; AYOLABI, EA (2009). Evaluation of Aquifer Vulnerability and the Protective Capacity in Some Oil Producing Communities of Western Niger Delta. Environmentalist, 29: 310-317

AYOLABI, EA (2005). Geoelectric Evaluation of Olushosun Landfill Site Southwest Nigeria and its Implication on Groundwater. J. of Geol. Soc. of India, 66: 318-322

OMATSOLA, ME; ADEGOKE, OS (1981). Tectonic Evolution and Cretaceous Stratigraphy of the Dahomey Basin. J. Mining Geology. 18(1): 130137

BALOGUN, OY (2000). Senior Secondary Atlas. Longman, Nigeria Plc
HASSANEIN, H; EL-KALIOUBY, H; AL-GARNI, MA (2007). The Use of DC Resistivity to Outline the Subsurface Hydrogeological and Structural Setting beneath a Proposed Site for Subsurface DAM Building, Makkah Al-Mukarramah, Saudi Arabia. J. of King Abdul Aziz Univ. Earth Sci., 18(1): 117-138

HENRIET, JP (1976). Direct Application of DarZarrouk Parameters in Ground Water Surveys. Geo. Pros., 24: 344-353

KOGBE, CA (1976). The Upper Cretaceous Abeokuta Formation of Southwestern Nigeria, Nigerian Field. 4(47): 48-52

LASHKARIPOUR, GR; SADEGHI, H; QUSHAEEI, $M$ (2005). Vertical Electrical Soundings for Groundwater Assessment in Southeastern Iran: A Case Study. J. of Appl. Geophy., 5(1): 973-977

MAILLET, R (1947). The Fundamental Equation of Electrical Prospecting. Geophy, 12: 529-556

OLADAPO, MI; MOHAMMED, MZ; ADEOYE, OO; ADETOLA, BA (2004). Geoelectrical Investigation of the Ondo State Housing Corporation Estate, Ijapo Akure, Southwestern Nigeria. J. of Min. and Geol., 40(1): 41-48

OLORUNFEMI, MO; FASUYI, SA (1993). Aquifer types, Geoelectric and Hydrogeologic Characteristics of Part of the Central Basement Terrain of Niger State Nigeria. J. of Afri Earth Sci., 16(1): 309-317

OLORUNFEMI, MO; OJO, JS; OLADAPO, MI (1998). Geological Hydrogeological and Geophysical Investigations of Exposed 20" Escravos Lagos Pipeline Technical Report

SØRENSEN, KI; AUKEN, E; CHRISTENSEN, NB; PELLERIN, L (2005). An Integrated Approach for Hydrogeophysical Investigations: New Technologies and A Case History. In: Butler DK (ed) Near-Surface Geophysics Vol 2, Society of Exploration Geophysics, 585-603

TELFORD, WM; GELDART, LP; SHERIFF, RE (1990). Applied Geophysics. Cambridge University Press, Cambridge. 